\title{
DUTY-TO-WARN-EVEN IF IT MAY BE HEARSAY? THE IMPLICATIONS OF A PSYCHOTHERAPIST'S DUTY-TO- WARN A THIRD PERSON WHEN INFORMATION IS OBTAINED FROM SOMEONE OTHER THAN HIS PATIENT
}

\author{
Deborah C. Edwards*
}

\section{INTRODUCTION}

On June 21, 2001, Geno Colello, a former member of the Los Angeles Police Department, had dinner with his parents. He was depressed and he told his father, Victor Colello, that he "hurt inside, and [did not] want to live anymore." He asked his dad to give him a gun because he wanted to commit suicide. His father refused. Geno said that instead of just killing himself, he was going to get a gun and "kill [the] kid"" that was romantically involved with his ex-girlfriend, and then kill himself. His father told him to "'buckle up' and not 'take the coward's way out."'3 Geno punched his father in the face and asked his father to take him to the hospital.

Victor contacted Geno's therapist, Dr. David Goldstein, whom Geno had been seeing for "work-related emotional problems and problems concerning his former girlfriend, Diana Williams." said, and Dr. Goldstein "urged [Victor] to take [Geno] to Northridge Hospital Medical Center, where Goldstein arranged for him to receive psychiatric care." Art Capilla, a licensed clinical social worker, met with Geno and his father when they arrived at the hospital. Capilla denied ever being told about Geno's threats. "Capilla asked [Geno] if he 'intended to kill . . . the new boyfriend.' The record does not reflect [Geno's] response."6 Later that day, Geno was voluntarily hospitalized. He was discharged on June 22, 2001 because he was found by a staff psychologist not to be suicidal, and the next day Geno murdered Williams' new boyfriend, Keith Ewing, and then committed suicide.

* J.D. Candidate, 2006, Indiana University School of Law_-Indianapolis; B.S. Business Management, 2001, Indiana University-Kelley School of Business, Indianapolis, Indiana. I would like to thank Erin Drummy Abraham for her help and insight. Most importantly, I would like to thank Leiann Dobbins and my son, Jonathan Edwards, for their understanding and support during the long hours spent researching and writing this note. 2004).

1. Ewing v. Northridge Hosp. Med. Ctr., 16 Cal. Rptr. 3d 591, 593-94 (Cal. Ct. App.

2. Id.

3. Id.

4. Ewing v. Goldstein, 15 Cal. Rptr. 3d, 864, 866 (Cal. Ct. App. 2004).

5. Id. at 867 .

6. Northridge Hosp., 16 Cal. Rptr. 3d at 594. 
Keith's parents sued Dr. Goldstein and Northridge Hospital. ${ }^{7}$ The Ewings alleged that Dr. Goldstein as well as Capilla "failed to discharge [their] duty to warn [Keith] or a law enforcement agency of the risk of harm" because Geno "posed a foreseeable danger to their son, and had directly or indirectly through third persons communicated to Goldstein [and Capilla] his intention to kill or cause serious physical harm to [Keith]."8

The trial court found for the hospital and Dr. Goldstein because " the patient himself had not communicated the threat to the therapist." In two separate rulings, the California Court of Appeals reversed the trial courts' rulings and, respectively, found Dr. Goldstein and Northridge Hospital Medical Center responsible for the wrongful death of Keith Ewing. ${ }^{10}$ The Northridge court stated that if a serious threat of "grave bodily injury" is communicated to the psychotherapist by a member of the patient's immediate family and is shared for the purpose of facilitating and furthering the patient's treatment, the fact that the family member is not a patient of the psychotherapist is not material. ${ }^{11}$

On November 10, 2004, the California Supreme Court denied both Dr. Goldstein's as well as Northridge Hospital Medical Center's petition for review. ${ }^{12}$ Therefore, the current law in the State of California, which may influence similar rulings in other jurisdictions, is that a psychotherapist has a duty-to-warn a third-person of any threat of serious bodily injury conveyed to the psychotherapist, not only from communications between the psychotherapist and the patient, but between the psychotherapist and a member of the patient's "immediate family."

7. The Ewings sued Dr. Goldstein for wrongful death based on professional negligence, and they sued Northridge Hospital alleging the hospital was vicariously liable for the acts of its employee, Art Capilla. Id.

8. Goldstein, 15 Cal. Rptr. $3 \mathrm{~d}$ at 867.

9. Northridge Hosp., 16 Cal. Rptr. 3d at 593 (emphasis added).

10. Goldstein, 15 Cal. Rptr. 3d at 864, 866; Northridge Hosp., 16 Cal. Rptr. 3d at 591, 593.

11. Northridge Hosp., 16 Cal. Rptr. 3d at 596 (emphasis added).

12. The Supreme Court of California did not publish an opinion on the reasons for denying review. However, Justices Baxter and Brown were both of the opinion that the petition should have been granted, but the majority denied the petition for review. Ewing v. Goldstein, 2004 Cal. LEXIS 11307 (Cal. 2004); Ewing v. Northridge Hosp. Med. Ctr., 2004 Cal. LEXIS 11295 (Cal. 2004). California Appellate Courts, Case Information, available at http:// appellatecases.courtinfo.ca.gov/search/dockets.cfm?dist $=2 \&$ doc_id $=162208 \&$ div $=8$ (last visited Mar. 8, 2005); California Appellate Courts, Case Information, available at http://appellate cases.courtinfo.ca.gov/search/dockets.cfm?dist $=0 \& d o c \_i d=338171$ (last visited Mar. 8, 2005).

13. Since the ruling in both Ewing decisions, the appellate courts' decisions have been recorded in publications to advise psychotherapists that the duty-to-warn may arise even if the danger is communicated from a patient's immediate family member. See $33 \mathrm{Cal}$. Forms of Pleading and Practice, Annotated 14, Ch. 380, Pt. I; 26 Cal. Forms of Pleading and Practice, Annotated 59, Ch. 304, Pt. IV (stating that:

although the statute states that the communication must come from the patient to trigger a duty to warn, the court of appeals has held that the duty to warn is 
This article begins in Part Two with the general history of privileges and continues with the United States Supreme Court's creation of the psychotherapist-patient privilege in federal court with the Court's decision in Jaffee $v$. Redmond. ${ }^{14}$ Part Three discusses the history of the psychotherapist's duty-to-warn a third party from information obtained during the confidential and privileged conversations with the patient. It begins with both holdings in Tarasoff v. Regents of Univ. of Cal. ${ }^{15}$ and continues with the current status of the duty-to-warn in the Sixth Circuit and the Ninth Circuit followed by examples of a few of the state courts including Texas, Pennsylvania and Delaware. Part Four explores the implications of both Ewing decisions from the California Court of Appeals. The court held that a psychotherapist has a duty-to-warn a third party when the information was obtained from someone other than the patient. The duty-to-warn includes a situation where no psychotherapist-patient relationship exists between the information-provider and the psychotherapist.

\section{History OF The Psychotherapist-PATIENT Privilege}

\section{A. Privileges in General}

Evidentiary privileges exist in an effort to balance the social costs of obtaining all necessary information for full realization of justice with the benefits of protecting sacred and privileged relationships. ${ }^{16}$ A privilege is granted in order to encourage communication between the parties protected by a particular privilege. The parties must strike a balance between maintaining the zones of privacy in a relationship and the right to defend oneself or prosecute claims in court by obtaining necessary evidence. ${ }^{17}$ Courts have found that the social cost of protecting these relationships far outweighs the testimonial benefits. ${ }^{18}$ Communication privileges are generally held to the following conditions:

also triggered under the statute if the threat of harm is communicated to the psychotherapist by a member of the patient's immediate family for the purpose of facilitating and furthering the patient's treatment.

Id. (emphasis added)).

14. Jaffee v. Redmond, 518 U.S. 1 (1996).

15. Tarasoff v. Regents of Univ. of Cal., 529 P.2d 553, 561 (Cal. 1974) (Tarasoff I); Tarasoff v. Regents of Univ. of Cal., 551 P.2d 334, 340 (Cal. 1976) (Tarasoff II).

16. Such privileged relationships include the relationship between an attorney and client, physician and patient, husband and wife, and priest and parishioner.

17. Christopher B. MuEller \& LAIRD C. KIRKPATRICK, EVIDENCE UNDER THE RULES 757 (5th ed. 2004) [hereinafter MUELLER].

18. HARVARD LAW REVIEW Ass'N, Evidence-Federal Testimonial Privilege-Ninth Circuit Holds That There is No Dangerous-Person Exception to the Federal PsychotherapistPatient Privilege-United States v. Chase, 340 F.3d 978 (9th Cir. 2003) (en banc), 117 HARV. L. REV. 996 (2004). 
(1) the privileged communications originate in confidence; (2) confidentiality is an essential element of the proper relationship between the parties; (3) the relationship is one that the community wishes to encourage; and (4) the injury caused by damaging the relationship through disclosure of the communications would be greater than the benefit gained. ${ }^{19}$

Early English common law established that a privilege existed between an attorney and client, but it was not until 1828, in New York, that an attorney-client privilege was recognized in the United States. ${ }^{20}$ A Senate Advisory Committee drafted thirteen proposed rules governing privileges. ${ }^{21}$ Controversy arose in Congress regarding the scope and propriety of any privileges being promulgated under the Rules Enabling Act. ${ }^{22}$ Congress was mainly concerned "about the omission of both the physician-patient privilege and the marital communications privilege"23 and about "the fact that the rules as promulgated would have applied to all actions in federal courts, overriding state privilege law, even where state law supplied the rule of decision."24 Congress responded by deleting the individual privilege provisions in the proposed rules and enacting the Federal Rule of Evidence $501 .{ }^{25}$ Federal Rule

19. Kinsella v. Kinsella, 696 A.2d 556, 565-66 (N.J. 1997).

20. Bruce Gross, Privileged Communication (May/June Annals 2002), available at $\mathrm{http} / / /$ michaelariens.com/evidence/acn1.htm\#ARTICLE\%20V (last visited Feb. 12, 2006).

21. While there were thirteen proposed rules governing privileges, the federal courts were required to recognize nine, which included: "required reports, lawyer-client, psychotherapistpatient, husband-wife, communications to clergy, political vote, trade secrets, secrets of state and other official information, and identity of informer." Michael Ariens, Legislative History to Federal Rules of Evidence, available at http://www.michaelariens.com/evidence/acn $1 . \mathrm{htm}$ (last visited Mar. 8, 2005).

22. The Rules Enabling Act provides that:

(a) The Supreme Court shall have the power to prescribe general rules of practice and procedure and rules of evidence for cases in the United States district courts (including proceedings before magistrate judges thereof) and courts of appeals.

(b) Such rules shall not abridge, enlarge or modify any substantive right. All laws in conflict with such rules shall be of no further force or effect after such rules have taken effect.

(c) Such rules may define when a ruling of a district court is final for the purposes of appeal under section 1291 of this title.

Rules Enabling Act, 28 USCA § 2072 (2004).

23. MUELLER, supra note 17 , at 758.

24. Id.

25. The Federal Rule of Evidence 501 states:

Except as otherwise required by the Constitution of the United States or provided by Acts of Congress or in rules prescribed by the Supreme Court pursuant to statutory authority, the privilege of a witness, person, government, State, or political subdivision thereof shall be governed by the principles of the common law as they may be interpreted by the courts of the United States in the light of 
of Evidence 501 states that absent Acts of Congress or Rules of the Supreme Court, privileges are "governed by the principles of the common law as they may be interpreted by the courts of the United States in the light of reason and experience."26

\section{B. The Psychotherapist-Patient Privilege}

\section{History of the Psychotherapist-Patient Privilege}

The proposed rules that were submitted to Congress in 1972 included the psychotherapist-patient privilege in proposed Federal Rule of Evidence $504 .^{27}$ " $[I]$ nherent in a Supreme Court recommendation of the psychotherapist-patient privilege is the Court's belief that confidentiality in psychotherapy would benefit both the patient and the public despite the evidentiary loss to society."28

Although the proposed rules were rejected, ${ }^{29}$ the Senate Judiciary Committee stated that even though it was only approving a general rule, it was not disapproving the recognition of any other privilege including:

psychiatrist-patient, or husband-wife, or any other of the enumerated privileges contained in the Supreme Court rules.

Rather, our action should be understood as reflecting the view that the recognition of a privilege based on a confiden-

reason and experience. However, in civil actions and proceedings, with respect to an element of a claim or defense as to which State law supplies the rule of decision, the privilege of a witness, person, government, State or political subdivision thereof shall be determined in accordance with State law.

FED. R. EVID. 501.

26. Id.

27. The general rule of privilege in the proposed Federal Rule of Evidence 504 was stated as follows:

(b) GeNERAL RULE OF PRIVILEGE. A patient has a privilege to refuse to disclose and to prevent any other person from disclosing confidential communications, made for the purposes of diagnosis or treatment of his mental or emotional condition, including drug addiction, among himself, his psychotherapist, or persons who are participating in the diagnosis or treatment under the direction of the psychotherapist, including members of the patient's family.

STEVEN GOODE \& OLIN GUY WELLBORN III, COURTROOM EVIDENCE HANDBOOK 2004-2005 STUDENT EDITION 135 (Thomson/West 2004) (1995). [hereinafter EVIDENCE HANDBOOK].

28. Huston Combs, Note, Dangerous Patients: An Exception to the Federal Psychotherapist-Patient Privilege, 91 KY. L.J. 457, 459-60 (2003). [Hereinafter Combs].

29. The Advisory Committee eliminated all of the specific rules on privileges and adopted a single rule, Rule 501, which left the law of privileges to current state and common law definitions. The Committee rationalized that federal law should not supersede that of the States in areas such as privilege while also being concerned with forum shopping in some civil actions. Legislative History to Federal Rules of Evidence, at http://www.michaelariens.com/evidence/ acnl.htm (last visited Mar. 8, 2005). 
tial relationship and other privileges should be determined on a case-by-case basis. ${ }^{30}$

Long before these proposed Rules of Evidence, the earliest psychotherapist-patient privilege case on record was decided on June 24, 1952 , by the Circuit Court of Cook County, Illinois in the case of Binder $v$. Ruvell..$^{31}$ The Binder court stated that because a psychiatrist is a physician, the relationship between a psychiatrist and a patient is the same as that of a physician and a patient, which was already a recognized privileged relationship. The Binder court reasoned that a psychiatrist works with his patient to find the cause of mental and emotional problems in the patient, and that his analysis must include all experiences of the patient while deeply probing the patient's thoughts and problems just to get patients to speak about their problems. ${ }^{32}$ The court continued by stating that courts should "guard the secrets which come to the psychiatrist," ${ }^{, 33}$ and a psychotherapist should not be allowed to disclose any of the secrets provided by the patient. The court concluded "it is just one of those cases [where] the [psychiatrist-patient] privilege ought to be granted and protected. And the social significance of it is probably even greater than that which comes from the protection of the communication between lawyer and client." 34

Twenty-four years after Binder, in May 1976, the Fifth Circuit was the first court to interpret the newly adopted Federal Rule of Evidence 501. In United States $v$. Meagher, ${ }^{35}$ the defendant argued that by allowing his psychotherapist to testify concerning their conversations, the court "violated his privilege, as a patient, against the disclosure of information confidential to a physician." ${ }^{\text {" Th }}$ The court reasoned that Rule 501 "states that unless otherwise provided, the privilege of a witness shall be governed by the principles of common law as interpreted by U.S. Courts in light of experience and reason."37 The court held that "[a]t common law, no physician-patient privilege existed and, therefore, we recognize no such privilege in federal criminal trial today. ${ }^{\mathrm{p3}}$

30. Id.

31. Committee on Mental Health, Psychiatric Communications Privileged, 150 JAMA 1241 (Nov. 22, 1952), available at http://Jaffee-Redmond.org/cases/binder.htm (last visited Mar. 7, 2005).

32. Id.

33. Id.

34. Id.

35. United States v. Meagher, 531 F.2d 752 (5th Cir. 1976).

36. Id. at 753 .

37. Id.

38. Id. The court further examined this case and privilege with regard to the Proposed Rule of Evidence, Rule 504. The court found that if the proposed rule had been enacted, the defendant in this case would fall under one of the exceptions to the proposed rule. This is because a defendant in a criminal trial that claims insanity as a defense cannot utilize the psychotherapist-patient privilege. The other two exceptions in the proposed rule were for (1) 
After the decision to recognize a psychotherapist-patient privilege was rejected in Meagher in 1976, other federal circuit courts addressed the same issue with differing conclusions. In 1983, the Sixth Circuit looked at the language of Proposed Rule 504 and balanced whether the confidentiality interest of the patient successfully outweighed the evidentiary need. The court found that "the balance tips in favor of the disclosure." 39 The court reasoned that although the main element of the privilege "is the assurance to the patient that his innermost thoughts may be revealed without fear," simply disclosing the patient's identity did not fall within the privilege. ${ }^{40}$ In that same year, the Seventh Circuit avoided the issue and ruled that the patient waives confidentiality when he gives his express consent to release the information to an insurance carrier, ${ }^{41}$ and the Eleventh Circuit ruled that confidentiality of medical records "[is] not absolute" and can be used as evidence. ${ }^{42}$ The Eleventh Circuit affirmed its decision in 1988 by definitively deciding that no psychotherapist-patient privilege should exist. ${ }^{43}$

Finally in 1992, the Second Circuit analyzed the Zuniga decision. ${ }^{44}$ The court looked to the forty-nine states and the district courts within the Second Circuit which had already enacted statutes establishing the psychotherapistpatient privilege. ${ }^{45}$ The court also examined cases in which the Courts of Appeals had not recognized the privilege." "Following this turmoil in the courts of appeals which spanned almost twenty years, the Supreme Court granted certiorari in Jaffee $v$. Redmond to decide this important question."

\section{The Supreme Court Recognizes the Psychotherapist-Patient Privilege}

It took until 1996 for the United States Supreme Court to establish the psychotherapist-patient privilege with its decision in Jaffee $v$. Redmond. Jaffee was decided forty-four years after Binder and twenty years after Meagher. The Court called the decision to recognize the psychotherapist-

proceedings for hospitalization stating that "no privilege under this rule for communications relevant to an issue in proceedings to hospitalize the patient for mental illness . .." and (2) examination by order of judge stating "[i]f the judge orders an examination of the mental or emotional condition of the patient, [these] communications . . . are not privileged . . .." EVIDENCE HANDBOOK, supra note 27, at 135.

39. In re Zuniga, 714 F.2d 632, 640 (6th Cir. 1983).

40. Id.

41. In re Pebsworth, 705 F.2d 261, 262 (7th Cir. 1983).

42. United States v. Lindstrom, 698 F.2d 1154, 1167 (11th Cir. 1983).

43. United States v. Corona, 849 F.2d 562, 566-67 (11th Cir. 1988).

44. In re Doe v. Diamond, 964 F.2d 1325, 1328 (2nd Cir. 1992).

45. Id.

46. Id.

47. Melanie Stephens Stone, Jaffee v. Redmond: The Supreme Court Adopts A Federal Psychotherapist-Patient Privilege and Extends the Scope to Encompass Licensed Social Workers, 48 MERCER L. REV. 1283, 1289 (1997). 
patient privilege as the "ultimate societal expression of the need to provide absolute protection from disclosure of communications between psychotherapists and their patients. ${ }^{\$ 48}$ The Court stated that the Jaffee privilege does not have as many years of common law experience as the attorney-client privilege, but it recognized that "[t]he way in which the new privilege develops is of major importance to all psychotherapists and their patients."49

\section{a. Facts in Jaffee v. Redmond ${ }^{0}$}

In Jaffee, Mary Lu Redmond received extensive counseling from a licensed social worker after a traumatic incident in which Mary $\mathrm{Lu}$, a police officer, shot and killed a man, Allen, while she was on duty. A suit was filed in federal district court claiming that Mary Lu "had violated Allen's constitutional rights by using excessive force during the encounter at the [scene]." ${ }^{\text {1 } 1}$ The fact that Redmond had been receiving counseling became apparent to the plaintiff during pre-trial discovery. ${ }^{52}$

\section{b. Procedural history in Jaffee v. Redmond ${ }^{3}$}

The plaintiff attempted to seek access to notes taken by social worker, Beyer, to use for cross-examination. ${ }^{54}$ The defendants resisted the discovery and asserted the notes "were protected against involuntary disclosure by a psychotherapist-patient privilege." 55 Even though the district judge rejected this argument, neither Beyer nor Redmond "complied with [the judge's] order to disclose the contents of Beyer's notes [and] [a]t depositions and on the witness stand both either refused to answer certain questions or professed an inability to recall details of their conversations." ${ }^{56}$ The district court judge instructed the jury "that the refusal to turn over Beyer's notes had no 'legal justification' and that the jury could therefore presume that the contents of the notes would have been unfavorable to respondents. The jury awarded petitioner $\$ 45,000$ on the federal claim and $\$ 500,000$ on her state-law claim." 57

48. The Federal Psychotherapist-Patient Privilege: History, Documents, and Opinions, available at http://Jaffee-Redmond.org (last visited Mar. 8, 2005).

49. Id.

50. Jaffee, 518 U.S. at 3-4.

51. Id. at 5.

52. Id.

53. Id.

54. Id.

55. Id.

56. Jaffee, 518 U.S. at 5-6.

57. Id. at 5-6. 
Addressing the issue for the first time, the Court of Appeals for the Seventh Circuit reversed and remanded for a new trial. ${ }^{58}$ The court stated 'that 'reason and experience,' the touchstones for acceptance of a privilege under Rule 501 of the Federal Rules of Evidence, compelled recognition of a psychotherapist-patient privilege." 59 The court explained that "[r]eason tells us that psychotherapists and patients share a unique relationship, in which the ability to communicate freely without the fear of public disclosure is the key to successful treatment. As to experience ... all [fifty] States have adopted some form of the psychotherapist-patient privilege."

\section{c. Decision and rationale in Jaffee $v$. Redmond ${ }^{6 l}$}

The case then moved to the Supreme Court which began its analysis by weighing the need for probative evidence with the need to recognize a psychotherapist-patient privilege. ${ }^{62}$ The Court called the public's right to "every man's evidence" a "fundamental maxim."63 Because the right for the public to hear all of a person's evidence is so imbedded in our judicial system, any exceptions, such as privileges, are "distinctly exceptional."64 The Supreme Court applied the same balancing test as the majority of other courts by weighing whether the public and private interests of those protected by the privilege were important enough to outweigh the fundamental maxim of using all available evidence in order to obtain the necessary truths. ${ }^{65}$

The Court began by comparing the husband-wife and attorney-client privileges with the psychotherapist-patient privilege due to their common vital need for confidence and trust. ${ }^{66}$ The Court concluded that because a psychotherapist's sessions depend on the patient willfully discussing potentially embarrassing facts, emotions, memories and fears, that if disclosed may cause embarrassment or disgrace to the patient, there is a need for the psychotherapist-patient privilege. ${ }^{67}$

58. Id. at 6.

59. Id.

60. Id. "The court also noted that, with one exception, the federal decisions rejecting the privilege were more than five years old and that the 'need and demand for counseling services has skyrocketed during the past several years." Id.

61. Jaffee, 518 U.S. at 15.

62. Id. at 9-10.

63. Id. at 9.

64. Id.

65. Id. at 11 .

66. Jaffee, 518 U.S. at 10.

67. Id. 


\section{PSYCHOTHERAPIST'S DUTY-TO-WARN REQUIREMENT}

\section{A. History of the Duty-To-Warn Requirement}

When Federal Rule of Evidence 501 was adopted, it was very general and it did not provide any specific exceptions to the rule except in instances where common law, the United States Constitution, United States Supreme Court, or Congress provided a specific privilege exception. When the Proposed Rule 504 was introduced, it included three specific exceptions to the psychotherapist-patient privilege ${ }^{68}$ but it did not include an exception regarding dangerous persons. The Advisory Committee believed that patients who opened up and confessed dangerous thoughts and feelings about other people were unlikely to go and commit the crimes. Also, if the patient knew their psychotherapist would be required to disclose the threat, the patient would not be free to communicate with his psychotherapist about all aspects of his problems that require treatment. "By intentionally excluding an exception for dangerous patients, the Advisory Committee showed great deference to the principle that the success of a psychotherapist depends upon his or her ability to communicate freely with a patient in a confidential setting." person exception to the psychotherapist-patient privilege to the courts, which led to the decisions in Tarasoff I and Tarasoff II.

In 1969, Prosenjit Poddar killed Tatiana Tarasoff two months after Poddar allegedly "confided his intention to kill" Tarasoff to his psychologist, Dr. Lawrence Moore. ${ }^{70}$ Finally in 1974 (Tarasoff I) and 1976 (Tarasoff II), five and seven years, respectively, after Tarasoff's death, the California Supreme Court, in Tarasoff I, ruled that the psychotherapists and the hospital

68. These exceptions in the Proposed Rule 504 read as follows:

(1) Proceedings for hospitalization. There is no privilege under this rule for communications relevant to an issue in proceedings to hospitalize the patient for mental illness, if the psychotherapist in the course of diagnosis or treatment has determined that the patient is in need of hospitalization.

(2) Examination by order of judge. If the judge orders an examination of the mental or emotional condition of the patient, communications made in the course thereof are not privileged under this rule with respect to the particular purpose for which the examination is ordered unless the judge orders otherwise.

(3) Condition an element of claim or defense. There is no privilege under this rule as to communications relevant to an issue of the mental or emotional condition of the patient in any proceeding in which he relies upon the condition as an element of his claim or defense, or, after the patient's death, in any proceeding in which any party relies upon the condition as an element of his claim or defense.

EVIDENCE HANDBOOK, supra note 27, at 135.

69. Combs, supra note 28 , at 461 .

70. Tarasoff v. Regents of Univ. of Cal., 551 P.2d 334, 339 (Cal. 1976) (Tarasoff II). 
involved in Poddar's care and treatment owed a duty-to-warn Tarasoff of the threats made by Poddar, ${ }^{71}$ and the court furthered this in Tarasoff II by also ruling the psychotherapists and hospital had a duty to protect Tarasoff from Poddar. $^{72}$ The Court stated, "[w]e conclude that the public policy favoring protection of the confidential character of patient-psychotherapist communications must yield to the extent to which disclosure is essential to avert danger to others. The protective privilege ends where the public peril begins."73

The Tarasoff II court further discussed the societal ills of its time. It described society as a "risk-infested society" unable to tolerate any more exposure to danger from concealing patient threats. ${ }^{74}$ The court concluded that in order to exercise reasonable care and, if possible, to protect an intended victim by providing a warning, "we see no sufficient societal interest that would protect and justify concealment. The containment of such risks lies in the public interest."75

\section{B. Current Status of the Duty-To-Warn Requirement}

\section{Federal Courts That Do Not Recognize the Duty-To-Warn Requirement}

\section{a. United States Court of Appeals-Sixth Circuit}

(I) Facts in United States v. Hayes ${ }^{76}$

Roy Lee Hayes was the union steward for a post office branch in Marion, Virginia where he worked his entire adult life. ${ }^{77}$ On February 9, 1998, "Hayes sought professional help at the Veterans Administration Mountain Home Hospital (MHH)" in Johnson City, Tennessee following erratic behavior at work and occasional depression so deep that he was unable to function. ${ }^{78}$ At $\mathrm{MHH}$ he was diagnosed with "major depression accompanied by severe psychotic features."79 During treatment, Hayes admitted to his psychotherapist, Dr. Dianne Hansen, his desire to kill his boss, Veda Odle. ${ }^{80}$ Hayes said that he could resist this urge because he knew such action would mean possibly losing his job. ${ }^{81}$ Dr. Hansen released Hayes on February

71. Tarasoff v. Regents of Univ. of Cal., 529 P.2d 553, 561 (Cal. 1974) (Tarasoff I).

72. Tarasoff II, 551 P.2d at 348.

73. Id. at 347.

74. Id.

75. Id.

76. United States v. Hayes, 227 F.3d 578, 580 (6th Cir. 2000).

77. Id. at 580.

78. Id.

79. Id.

80. Id.

81. Hayes, 227 F.3d at 580. 
18 and told him he could go back to work on February $23 .^{82}$ She also instructed him to contact his health care provider. It was noted in MHH's records that Dr. Hansen planned on warning Odle of the threat, but "it is undisputed the Odle never received any warning from the staff at MHH." ${ }^{\text {83 }}$

On March 31, Hayes attended a session with James Van Dyke at the Veterans Center in Johnson City, Tennessee. ${ }^{84}$ This time Hayes described, in great detail, how he planned to kill Odle. He even fully described the layout of Odle's home as well as his knowledge of "when she would be home alone." 85 Van Dyke advised Hayes that these threats "could not be kept confidential." ${ }^{86}$ Van Dyke waited until the next day to warn Odle of the threats and did so after speaking with the Veterans Center's legal counsel and being advised he had a legal obligation to warn Odle of the threat that Hayes posed. ${ }^{87}$

\section{(II) Procedural history in United States v. Hayes ${ }^{88}$}

A magistrate judge held "that the 'threat' revealed to Odle by Van Dyke was not privileged because that revelation was the 'only means' of averting harm to Odle." ${ }^{89}$ The district court, however, held to the contrary because it found Van Dyke's disclosure of information was not "the only means of averting harm," and he could not testify at trial. ${ }^{90}$ The court then granted Hayes' motion to exclude the testimony of his psychotherapists. The psychotherapists' testimony was the basis of all of the charges brought against Hayes. The district court then dismissed the case and the government immediately appealed.

\section{(III) Holding and reasoning in United States v. Hayes ${ }^{91}$}

The Sixth Circuit court in Hayes held there is not a dangerous person exception to the federal psychotherapist-patient privilege. ${ }^{92}$ The psycho-

\section{Id.}

83. Id.

84. James Van Dyke was employed as a social worker at the Veterans Center in Johnson City, Tennessee. $I d$.

85. Id. at 580 .

86. Hayes, 227 F.3d at 580.

87. Id.

88. Id. at 581. (All procedural history in following paragraphs is found in U.S. v. Hayes, 227 F.3d 578, 581 (6th Cir. 2000)).

89. Id.

90. Id.

91. Hayes, 227 F.3d at 580.

92. Id. at 584-85. 
therapist does not have a professional or ethical duty to protect third persons. ${ }^{93}$ The court gave three distinct reasons for rejecting the duty-to-warn. ${ }^{94}$

First, the court cautioned that there would be a chilling effect from the knowledge that the psychotherapist has a duty-to-warn concerning statements made by the patient to the psychotherapist. The court reasoned that the chilling effect would be even greater if the patient is aware his statements can be used against him in a criminal proceeding. ${ }^{95}$ The court recognized both the importance placed on mental health by the Supreme Court and the consequences of a dangerous person exception. ${ }^{96}$ The Hayes court indicated a dangerous person exception "would have a deleterious effect on the 'atmosphere of confidence and trust' in the psychotherapist/patient relationship." 97

Second, the Hayes court looked to the ways the exception would serve the public interest. ${ }^{98}$ It referred to Jaffee footnote $19^{99}$ in recognizing two interests: (1) 'the improvement of our citizens' mental health achieved, in part, by open dialogue in psychotherapy ... and [2] the protection of innocent third parties. . . "100 Because both are public concerns, the Hayes court believed Jaffee footnote 19 was "no more than an aside by Justice Stevens to the effect that the federal psychotherapist/patient privilege will not operate to impede a psychotherapist's compliance with the professional duty to protect identifiable third parties from serious threats of harm." ${ }^{101}$ Lastly, the court stated that "reason and experience" have taught us that adopting a dangerous person exception in federal common law would be "ill-advised."102

\section{b. United States Court of Appeals-Ninth Circuit}

(I) Facts in United States v. Chase ${ }^{103}$

During numerous sessions with his psychiatrist, Dr. Kay Dieter, Steven Chase disclosed that he had a list of people written in his day planner that he planned to kill. He showed the day planner to Dr. Dieter, but Chase told Dr.

93. Id. at 586.

94. Id. 584-86.

95. Hayes, 227 F.3d 578, 585.

96. Id.

97. Id. at 584 .

98. Id. at 585 .

99. The Hayes court is referring to Footnote 19 of the Jaffee opinion which reads: Although it would be premature to speculate about most future developments in the federal psychotherapist privilege, we do not doubt that there are situations in which the privilege must give way, for example, if a serious threat of harm to the patient or to others can be averted only by means of a disclosure by the therapist.

Jaffee v. Redmond, 518 U.S. 1, 18 n.19 (1996).

100. Hayes, 227 F.3d at 585 .

101. Id.

102. Id. at 585-86.

103. United States v. Chase, 340 F.3d 978, 979-81 (9th Cir. 2003). 
Dieter that "he had no intention to act immediately on his homicidal thoughts." 104 A few months later, Chase became upset after an argument with his wife. He called Dr. Dieter and told her about a life insurance policy he had that would pay if something should happen to him. In light of fears that Chase was losing his support system, and after discussion with the legal department at her treatment facility, Dr. Dieter contacted local police who then contacted the FBI. ${ }^{105}$ Dr. Dieter testified concerning the contents of these therapeutic sessions.

\section{(II) Procedural history in United States v. Chase ${ }^{106}$}

At trial, Chase challenged the admissibility of Dr. Dieter's testimony under the psychotherapist-patient privilege. ${ }^{107}$ "The district court held that Dr. Dieter's testimony was admissible" reasoning "that the federal psychotherapist-patient privilege did not apply because ... [Chase's] threats were serious when uttered, that harm was imminent, and that disclosure to authorities was the only means of averting the threatened harm." ${ }^{108}$ Chase was found guilty and appealed the conviction. A three-judge panel affirmed both the court's ruling and the conviction. The Ninth Circuit court agreed to hear the case en banc.

\section{(III) Holding and reasoning in United States v. Chase $e^{109}$}

The Ninth Circuit Court first discussed the Oregon state law because Chase's counseling sessions were conducted in Oregon. Oregon has a discretionary exception to the confidentiality requirement between a psychotherapist and patient. Relying on this rule as well as Jaffee footnote 19, the Chase court held that Dr. Dieter properly disclosed the threats. ${ }^{110}$ However, the main issue of the case rested on whether the court should recognize a dangerous

104. Id. at 979.

105. The FBI was contacted because Chase's list contained the names of two FBI agents he wanted to kill as revenge for not adequately protecting him. Id. at 981 .

106. Chase, 340 F.3d at 979.

107. Id. at 981 .

108. Id.

109. Chase, 340 F.3d at 992.

110. Id. at 985 . The court first looked at how confidentiality between a patient and physician is protected by various statutes in Oregon including OR. REV. STAT. $§ 677.190(5)$ (2003) (stating that " $[w]$ illfully or negligently divulging a professional secret without the written consent of the patient" is grounds for revoking or refusing to grant a license, registration or certification to practice medicine); OR. REV. STAT. $\$ 430.399(5)$ (2003) (stating "[ $[$ ]he records of a patient at a treatment facility shall not be revealed to any person other than the director and staff of the treatment facility without the consent of the patient."); and OR. REV. STAT. $\$ 40.230$ (2005) (stating a patient may refuse to disclose and prevent anyone else from disclosing, "confidential communications made for the purposes of diagnosis or treatment ..."). 
patient exception to the federal testimonial privilege, which may arise from the dangerous-patient exception in state rules of confidentiality. ${ }^{111}$

The Chase court declined to recognize a dangerous-patient exception to the federal testimonial privilege. ${ }^{112}$ The court reasoned that allowing the exception to the federal testimonial privilege would "significantly injure the interests justifying the existence of the privilege; would have little practical advantage; would encroach significantly on the policy prerogatives of the states; and would go against the experience of all but one of the states in our circuit, ${ }^{113}$ as well as the persuasive Proposed Rules."114

\section{Texas Does Not Recognize the Duty-to-Warn Requirement}

\section{a. Facts in Thapar v. Zezulka ${ }^{115}$}

Dr. Renu Thapar was a psychiatrist who had been treating Freddy Ray Lilly since 1985 . $^{116}$ Lilly was diagnosed "as suffering from moderate to severe post-traumatic stress disorder, alcohol abuse, and paranoid and delusional beliefs concerning his stepfather, Henry Zezulka, and people of certain ethnic backgrounds." 117

In 1988, Lilly told Dr. Thapar that he felt like killing Henry Zezulka but that he had decided not to go through with it. ${ }^{18}$ Within a month after his release, Lilly shot and killed Henry Zezulka. ${ }^{119}$ Dr. Thapar did not warn Zezulka or law enforcement officials of Lilly's threat. ${ }^{120}$

111. Chase, 340 F.3d at 985 . The Oregon exception applies to the confidentiality requirement. The rule to which the court is referring does not impose neither a duty to disclose the threat nor any civil liability on the psychotherapist for failing to disclose the threat. The statute reads as follows:

(12) Information obtained in the course of diagnosis, evaluation or treatment of an individual that, in the professional judgment of the health care services provider, indicates a clear and immediate danger to others or to society may be reported to the appropriate authority. A decision not to disclose information under this subsection does not subject the provider to any civil liability.

OR. REV. STAT. § 179.505(12) (emphasis added).

112. Chase, 340 F.3d at 991.

113. Id. at 992. The court analyzed the dangerous-person exception in the State of Washington. In Washington, the therapist can testify under the dangerous-patient exception "because his therapist permissibly had disclosed a communication under state law." Id. at 988.

114. Id. Referring to Proposed Rule 504 of the Federal Rules of Evidence.

115. Thapar v. Zezulka, 994 S.W.2d 635, 636 (Tex. 1999).

116. Id.

117. Id.

118. Id.

119. Id.

120. Thapar, 994 S.W.2d at 636. 


\section{b. Holding and Reasoning in Thapar v. Zezulka ${ }^{121}$}

Appealing from a summary judgment, the Texas Supreme Court viewed evidence in the light most favorable to Lyndall Zezulka, the nonmovant. ${ }^{122}$ The court began its analysis by determining whether or not a duty exists to warn a third-party of a patient's threat by looking to the confidentiality statute that governs the mental health profession in the State of Texas. Three years after Tarasoff II in 1979, the Texas Legislature enacted a statute "governing the disclosure of communications during the course of mental-health treatment." 123 Texas' confidentiality rule does not have an exception that allows disclosure to third parties, though the rule permits disclosure of confidential information to medical or law enforcement personnel. ${ }^{124}$

Nonetheless, the court stated that "[i]mposing a legal duty to warn third parties of patient's threats would conflict with the scheme adopted by the Legislature by making disclosure of such threats mandatory," 125 and that imposing a common-law duty to warn on mental-health professionals imposes a "[c]atch-22. They either disclose a confidential communication that later proves to be an idle threat and incur liability to the patient, or they fail to disclose a confidential communication that later proves to be a truthful threat and incur liability to the victim and the victim's family."126 The Thapar court stated, "we decline to adopt a duty to warn now because the confidentiality statute governing mental-health professionals in Texas makes it unwise to recognize such common-law duty.",127

121. Thapar, 994 S.W.2d at 640 (Tex. 1999).

122. Id. at 636 .

123. Id. at 638. Today, the statute the Thapar court referred to reads as follows:

Communications between a patient and a professional, and records of the identity, diagnosis, evaluation, or treatment of a patient that are created or maintained by a professional, are confidential. (b) Confidential communications or records may not be disclosed except as provided by Section 611.004 or 611.0045. (c) This section applies regardless of when the patient received services from a professional.

TEX. HEALTH \& SAFETY CODE ANN. $§ 611.002$ (2004).

124. See TEX. HEALTH \& SAFETY CODE ANN. § 611.004(a)(2) (2005) (which reads: (a) A professional may disclose confidential information only: (2) to medical or law enforcement personnel if the professional determines that there is a probability of imminent physical injury by the patient to the patient or others ...") (emphasis added).

125. Thapar, 994 S.W.2d at 639.

126. Id. at 640 .

127. Id. at 638 . 
3. States That Recognize the Duty-To-Warn Requirement ${ }^{128}$

\section{a. Pennsylvania}

(I) Facts in Emerich v. Philadelphia Ctr. for Human Dev., Inc. ${ }^{129}$

On June 27, 1991, Gad Joseph fatally shot his girlfriend, Teresa Hausler. Prior to doing so, he called his counselor, Anthony Scuderi, to inform him of his intentions. Scuderi immediately met with Joseph during an emergency therapy session and suggested Joseph admit himself to a psychiatric hospital. Joseph refused this suggestion stating that, "he was in control and would not hurt Ms. Hausler."130 Based on this statement, Scuderi let Joseph leave the session. About thirty minutes later, Joseph shot and killed Hausler after which he telephoned Scuderi. ${ }^{131}$ Scuderi, upon direction of the executive director of the Center, notified police. ${ }^{132}$

\section{(II) Procedural history in Emerich v. Philadelphia Ctr. for Human Dev., Inc. ${ }^{133}$}

After Joseph was convicted of murder, Hausler's estate brought suit against the treatment center, Scuderi, and the director of the Center. The trial court granted judgment in favor of the Health Center and the Superior Court affirmed by reiterating the trial court's reasoning that at the time of the ruling, there was no duty-to-warn a third party requirement in Pennsylvania law. However, if such a duty did exist, "[a]ppellant failed to establish a cause of

128. To date, the only federal court to recognize an exception to the psychotherapist-patient privilege is the Tenth Circuit Court of Appeals. The Tenth Circuit relied on footnote 19 in Jaffee when it remanded a case to the district court to determine whether the threat made by the defendant "was serious when it was uttered and whether its disclosure was the only means of averting harm to the President when the disclosure [by the psychotherapist] was made." United States v. Glass, 133 F.3d 1356, 1360 (10th Cir. 1998). (Upon voluntarily entering a hospital for ongoing mental illness, Glass stated to his psychotherapist that he wanted to shoot President and Mrs. Clinton in order "to get in the history books." Id. at 1357. Days later Glass was released on condition that he remain with his father and attend outpatient therapy. Id. Ten days later, only after discovering Glass had left his father's residence, local law enforcement and ultimately the Secret Service were advised of Glass' threats against President and Mrs. Clinton. Id. Because there was a ten day interval between the threat and the notification of law enforcement, the Tenth Circuit Court remanded the case to the district court to determine the extent of the seriousness of Glass' threat. Id. at 1357-60.

129. Emerich v. Philadelphia Ctr. for Human Dev., Inc., 720 A.2d 1032, 1034 (Pa. 1998).

130. Id. at 1035.

131. Id.

132. $I$ d.

133. Emerich, 720 A.2d at 1035. 
action as his decedent was killed when she ignored Mr. Scuderi's warning not to go to Joseph's apartment."134

\section{(III) Rationale in Emerich v. Philadelphia Ctr. for Human Dev., Inc. ${ }^{135}$}

In a case of first impression, the Supreme Court of Pennsylvania stated, "the concept of a duty to protect by warning, albeit limited in certain circumstances, has met with virtually universal approval." 136 The Emerich court relied on public policy principles when it found a duty-to-warn. The court looked to duty and the concept that duty "'amounts to no more than the sum total of those considerations of policy which led the law to say that the particular plaintiff is entitled to protection from the harm suffered." 137 Continuing its analysis, the court examined the societal interest regarding the protection of Pennsylvania's citizens from harm by imposing the duty-to-warn. "Simply stated, it is reasonable to impose a duty on a mental health professional to warn a third party of an immediate, known and serious risk of potentially lethal harm."138

\section{b. Delaware}

\section{(I) Facts in State of Del. v. Bright ${ }^{139}$}

Rodney . Bright was a United States veteran and had been seeking treatment at various Veterans' Administration facilities for over twenty years. Bright was diagnosed and suffered from manic depression and bi-polar disorder. He had made various threats to harm his ex-wife, but it was not until December 9, 1994, that Bright contacted his psychiatrist, Dr. Mayetta, and told her that he was leaving that day to drive to Delaware to kill is ex-wife. He told Dr. Mayetta that "he had several weapons" and he was either going to shoot [his ex-wife] or "strangle her with his bare hands." 140 Dr. Mayetta contacted local law enforcement officials. Bright was consequently arrested only a mile and half from his ex-wife's workplace. At the time of his arrest, Bright possessed a knife, duct tape and rope.

134. Id. at 1035 .

135. Emerich, 720 A.2d at 1043.

136. Id. at 1037.

137. Id. at 1039. (quoting Mazzagatti v. Everingham By Everingham, 516 A.2d 672, 678

(Pa. 1986)).

138. Id.

139. State of Del. v. Bright, 683 A.2d 1055, 1058-59 (Del. Super. Ct. 1996).

140. Id. at 1058 . 


\section{(II) Procedural History in State of Del. v. Bright ${ }^{141}$}

The Bright case was an opinion issued upon Bright's Motions to Suppress. "Bright filed two Motions to Suppress certain evidence relating to statements made by him to medical personnel at an out-of-state Veterans' Administration Hospital."142 One of Bright's grounds to suppress the evidence was that Dr. Mayetta violated the physician-patient privilege when she disclosed the threatening statements to law enforcement officials. ${ }^{143}$

\section{(III) Rationale in State of Del. v. Bright ${ }^{144}$}

The Delaware Superior Court held that Dr. Mayetta's disclosure of Bright's threats against his ex-wife did not violate the psychotherapist-patient privilege. ${ }^{145}$ The court began its discussion on the issue of the psychotherapist-patient privilege by recognizing that "confidentiality statutes exist along with the well-recognized law of privileges, ... [and that] [ $t$ ]he federal statutes and the law of privilege both encompass a similar purpose: to facilitate communication between the patient and the therapist."146 Since

141. Id. at 1058-59 (Del. Super. Ct. 1996).

142. Id. (At the time of his treatment, Bright was seeking medical attention from Dr. Mayetta at a Veterans' Administration facility in Indianapolis, Indiana.)

143. Id. at 1059. Bright's other bases for his claim were (or included) that "Dr. Mayetta acted as an agent for the prosecution when she questioned Bright; thereby, rendering his statements involuntary under the Fifth Amendment . . . [and] that a federal confidentiality statute, 42 U.S.C. $\S 290 \mathrm{dd}-2$ (c), prohibit[ed] the use of records relating to substance abuse programs in criminal proceedings." Bright, 683 A.2d at 1059. On these points, the Delaware Superior Court held that Dr. Mayetta did not violate Bright's Fifth Amendment rights when he reported the threatening remarks. Id. at 1065. Distinguishing from United States v. D.F., 63 F.3d 671 (7th Cir. 1995), the court held that Dr. Mayetta "was not acting as an agent for the [government] merely because she was employed by a government facility." Bright, $683 \mathrm{~A} .2 \mathrm{~d}$ at 1060. Furthermore, she "did not coerce Bright into confessing his involvement in any crime so that he could be punished[; . . . [but] [i]nstead [she] attempted to treat Bright for his mental [conditions] ... during which she discovered" his intention to harm his ex-wife. Id. at 1060-61. The court also found that the federal confidentiality statute did not apply to the given situation due to Bright's reliance on a statute that applied to persons being treated in federally assisted drug and/or alcohol treatment programs. Because Bright wasn't being treated for drug or alcohol abuse and the disclosure of the statements was not derived from treatment of drug or alcohol abuse counseling, the federal statutes did not apply in this case. Id. at 1062.

144. Bright, 683 A.2d 1064.

145. Id.

146. Id. The court referred to the Delaware Physician and Psychotherapist-Patient Privileged statute in footnote 16 of the opinion, which reads, in part:

(1) A communication is 'confidential' if not intended to be disclosed to third persons...." and

(b) General rule of privilege. A patient has a privilege to refuse to disclose and to prevent any other person from disclosing confidential communications made for the purpose of diagnosis or treatment of the patient's physical, mental or emotional condition, including alcohol or drug addiction, among the patient, the patient's mental health provider, physician or psychotherapist, and persons who 
confidentiality statutes and laws of privilege can co-exist, the exceptions to these statutes and laws can also co-exist. The court identified the duty-towarn exception as a "well established exception."147 Quoting the reasoning in Tarasoff II as well as another Delaware Supreme Court case, ${ }^{148}$ the Bright court stated that not only do "mental health professionals have a duty of confidentiality to their patients, they also have an affirmative duty to persons other than the patient to exercise reasonable care in the treatment and discharge of such patients."149 The court defined reasonable care to include "a 'duty to warn potential victims or a class of potential victims and/or control, to some appropriate degree, the actions of the patient." 150

\section{THE IMPLICATIONS OF THE EWING DECISIONS}

\section{A. Holding and Rationale in Ewing v. Goldstein ${ }^{151}$}

In the Ewing decisions, the courts extended a statute and statutory definitions beyond their ordinary meanings. Ewing $v$. Goldstein was the first of the two Ewing cases to be decided. ${ }^{152}$ The appellate court reviewed the trial court's construction of California Civil Code 43.92 and determined that it was "unduly narrow."153 The trial court determined "the Ewings had failed to satisfy the statutory requirements necessary to defeat the psychotherapist's immunity, because 'the patient himself' had not communicated the threat to the therapist." 154

California Civil Code section 43.92 establishes the duty of a psychotherapist to warn and protect an identifiable third person. ${ }^{155}$ The statute bars any

Monetary liability on the part of, and no cause of action shall arise against, any person who is a psychotherapist . . . in failing to warn of and protect from a patient's threatened violent behavior or failing to predict and warn of and protect

are participating in the diagnosis or treatment under the direction of the mental health provider, physician or psychotherapist, including members of the patient's family.

DEL. CODE ANN. D.R.E. §§ 503(a)(4), (b) (1996).

147. Bright, 683 A.2d at 1064 .

148. The other Delaware Supreme Court case that the Bright court relied on was Naidu v. Laird, 539 A.2d 1064 (Del. 1988).

149. Bright, 683 A.2d at 1064 (emphasis added).

150. Id. (quoting Naidu, 534 A.2d at 1073 (Del. 1988)).

151. Goldstein, 15 Cal.Rptr.3d at 875.

152. Id.

153. Id. at 868 .

154. Id.

155. CAL. Civ. CODE § 43.92(a) (West 2004). 
from a patient's violent behavior except where the patient has communicated to the psychotherapist a serious threat of physical violence against a reasonably identifiable victim or victims. ${ }^{156}$

The court of appeals began its analysis by looking at the statutory construction of this statute. Quoting a 2002 California Court of Appeals case, Allen v. Sully-Miller Contracting Co. ${ }^{157}$ the court stated, "“[u]ltimately we choose the construction that comports most closely with the apparent intent of the lawmakers, with a view to promoting rather than defeating the general purpose of the statute."'158

The court then looked at balancing the interests the statute was protecting and finally examined whether the information can come from the patient's family. "A 'patient' is defined as 'a person who consults a psychotherapist or submits to an examination by a psychotherapist for the purpose of securing a diagnosis or preventive, palliative, or curative treatment of his mental or emotional condition."159

The court recognized the dichotomy present in Section 43.92. "Section 43.92 represents a legislative effort to strike an appropriate balance between conflicting policy interests." ${ }^{\text {"60 }}$ The policy interest the court refers to is the "need to preserve a patient confidence [in order to achieve] an effective diagnosis and treatment of a mental illness or an emotional problem [that can be] severely undermined when a patient cannot be assured that a statement made in the privacy of his therapist's office will not be revealed."161 The conflicting interest as stated by the court is "under limited circumstances, preserving a confidence is less important than protecting the safety of someone whom the patient intends to harm."162 The court determined that this balancing of interests did not apply in this case because there was not a confidence to be protected.

This is because the confidence arises from the confidential relationship between a psychotherapist and the patient. Victor Colello was not in any type of relationship with Dr. Goldstein that would trigger the confidence. The confidential relationship was between Geno and Dr. Goldstein. Requiring Dr. Goldstein to warn Keith Ewing was not warranted because there was no confidence that needed protecting and therefore, no duty should have been imposed.

156. Id.

157. Allen v. Sully-Miller Contracting Co., 120 Ca. Rptr. 2d 795 (Cal. Ct. App. 2002).

158. Goldstein, 15 Cal. Rptr. 3d at 869. (quoting Sully-Miller Contracting Co., 120 Cal. Rptr. 2d at 798).

159. Id. (emphasis added) (quoting Cal. Evid. Code §1011).

160. Id. at 871 .

161. Id.

162. Id. (emphasis added). 
Prosser says that "duty" is the only word in law where the conclusion of liability is stated in just one word. ${ }^{163}$. He continues that "many factors interplay: the hand of history, our ideas of morals and justice, the convenience of administration of the rule, and our social ideas as to where loss should fall."164 A classic English definition of duty maintains that "when circumstances place one individual in such a position with regard to another ... ordinary sense would recognize the danger of injury to the other ...."165 In this case, it would take more than simple ordinary sense for Dr. Goldstein or Northridge Hospital Medical Center to recognize the danger that Geno posed to Keith Ewing. There was no communication from Geno, and a dutyto-warn requirement normally emerges out of the private, confidential communications between a doctor and the patient.

The Goldstein court also determined that a situation:

when the communication of the serious threat of physical violence is received by the [psycho] therapist from a member of the patient's immediate family ${ }^{166}$ and is shared for the purpose of facilitating and furthering the patient's treatment, the fact that the family member is not technically a 'patient' is not crucial to the statute's purpose. ${ }^{167}$

163. William L. Prosser, Palsgraf Revisited, 52 Mich. L. Rev. 1, 15 (1953).

164. Id.

165. Marshall S. Shapo, The Duty to Act: Tort Law, Power \& Public Policy xi (Univ. of Tex. 1977) (emphasis added).

166. Goldstein, 15 Cal. Rptr. 3d at 871-72. The Goldstein court did not definitively define "immediate family" member. There are many differing definitions of "immediate family" in California codes. See CAL. BuS. \& PROF. CODE § 3625(c)(2)(West 2004) (defining "immediate family" as "spouse, parents, children, or his or her children's spouses"); CAL. EDUC. CODE § 67360(c)(1) (West 2004) (defining "immediate family" as "spouse, child, parent, stepparent, grandparent, grandchild, brother, sister, parent-in-law, brother-in-law, sister-in-law, nephew, niece, aunt, uncle, or first cousin, or the spouse of any of those persons, or guardian of any of those persons"); CAL. GOV'T CODE $\S 51230.1$ (c) (West 2004) (defining "immediate family" as "spouse of the landowner, the natural or adopted children of the landowner, the parents of the landowner, or the siblings of the landowner"); CAL. GOV'T CODE $\S 82029$ (West 2004) (defining "immediate family" as "spouse and dependent children"); CAL. PENAL CODE $\S$ 217.1(c)(1) (West 2004) (defining "immediate family" as spouse, child, stepchild, brother, stepbrother, sister, stepsister, mother, stepmother, father, or stepfather); CAL. PENALCODE $\S 422$ (West 2004) (defining "immediate family" as "any spouse, whether by marriage or not, parent, child, any person related by consanguinity or affinity within the second degree, or any other person who regularly resides in the household, or who, within the prior six months, regularly resided in the household"); CAL. ST. RULES APP. DIV. 6 STANDARD 2N (West 2005) (defining "immediate family" as "spouse or domestic partner and any minor child living in the arbitrator's household").

167. Goldstein, 15 Cal. Rptr. 3d at 871-872 (emphasis added). 
The court reasoned that a person's emotional problems do not "exist in a vacuum"168 and discussed that all aspects of the patient's life have an impact on the patient's emotional and mental health. The court stated that even if communication during therapy is given by a family member, these communications need to be protected in order to further "the patient's therapy by giving the therapist a fuller understanding of the problem or illness for which his or her expertise is needed by encouraging the patient and his or her family members to fully disclose information they might otherwise be embarrassed or reluctant to reveal." 169

Therefore, the court is trying to extend the blanket of confidentiality over the patient's immediate family member. Congress refused to enact legislation to add the psychotherapist-patient privilege to the Federal Rules of Evidence by enacting Rule 501 instead. It took many state courts and finally federal courts over twenty years to even begin to recognize the need and requirement of a psychotherapist-patient privilege. Now, the California Court of Appeals has broadened this privilege and has extended this confidentiality to immediate family members of the patient by saying this communication has to be protected in order to further the treatment and diagnosis of the patient. This goes far beyond the scope and intent of the California statute.

The court wants to make sure that a patient's treatment is achieved by protecting the immediate family member's communications about diagnosis and treatment and holding the doctors and hospital liable for these types of communications. However, neither of the Ewing decisions specifically defined "immediate family member." Knowing there are differing definitions of "family member" within California legislation, ${ }^{170}$ the court stated that this case and opinion does not address or concern situations where someone other than a patient's immediate family "conveys the information of the patient's potential dangerousness to the therapist."171 The court was very concerned about applying the balancing test between ensuring the patient was being treated and protecting the intended third-party victim. Why stop with immediate family members if the most important thing is to protect the victim and further the patient's treatment for mental illness?

\section{B. Holding and Rationale in Ewing v. Northridge Hosp. Med. Ctr. ${ }^{172}$}

The Northridge case was decided only eleven days after the Goldstein case. It was argued before the same court and the same judge wrote both opinions. The Northridge decision relied entirely on the opinion in Goldstein

168. Id. at 872 .

169. Id. (emphasis added).

170. See supra text accompanying note 166 .

171. Goldstein, 15 Cal. Rptr. 3d at 873 n.10.

172. Ewing v. Northridge Hosp. Med. Ctr., 16 Cal. Rptr. 3d 591, 593-94 (Cal. Ct. App. 2004). 
and stated "[ $t]$ he pivotal factual question is whether the psychotherapist actually held the belief or made the prediction. If so, it does not matter that the belief or prediction was premised, in some measure, on information derived from a member of the patient's family." 173

The California statute on which both Ewing courts rely does not mention anything about the psychotherapist actually holding a belief or prediction of the violent propensities of the patient. Instead, the statute specifically states that there is a duty when the patient has communicated the threat to the psychotherapist. ${ }^{174}$

\section{Slippery Slope the California Court of Appeals Has Created}

Both Ewing courts claim that part of each decision is based on the statutory construction and the legislative intent of a statute, but instead of clearing up any discrepancies, inconsistencies or confusions, they have created them. The courts went beyond the scope of a statute that was enacted to protect a long-held psychotherapist-patient privilege. The statute allowed only one exception to this well-recognized privilege that protects a patient's privacy and confidentiality during the patient's mental health treatments. The Ewing courts have taken this one exception and have now opened the floodgates of litigation. The door has been opened for more people to claim that some person told another person that they were going to injure someone else, and then ultimately hold the doctor to an affirmative duty on this thirdparty information.

California Code section 43.92(a) plainly states that the communication must come from the patient to the psychotherapist. ${ }^{175}$ The Ewing courts went too far outside the bounds of the statute and legislative intent. The general rule for statutory construction in California states, "the judge is simply to ascertain and declare what is in terms or in substance contained therein, not to insert what has been omitted, or to omit what has been inserted. . . "176 The majority certainly inserted "family member" into this statute and thus broadened the definition of "patient communication," which, in turn, broadened the statute. If the legislature intended to include family members in the statute, it would have done so, especially given the numerous definitions of family member provided in certain California codes. ${ }^{177}$

The Ewing courts have also brought confusion into the California mental health profession. Until now, psychotherapists in California have had a dutyto-warn an intended third party of imminent harm from threats made by the psychotherapist's patient. Now a psychotherapist has to try and determine

173. Id. at 596 (emphasis added).

174. CAL. CIv. CODE § 43.92(a) (West 2005).

175. Id.

176. CAL. Civ. Proc. CodE $\S 1858$ (Deering 2004).

177. See supra text accompanying note 166. 
whether or not the information provided by a patient's family member imposes this same duty. In almost all circumstances, the family member will not be a patient of the psychotherapist. The psychotherapist will have to determine the mental state of the person conveying the information by determining not only whether the threat can cause imminent harm to an intended third-party victim but also whether the threat is valid. It will be nearly impossible, without obtaining the necessary background and history, for the psychotherapist to properly assess the mental state of the information provider ("family member") and to ultimately decide if the information that has been provided triggers the duty-to-warn requirement.

The California Supreme Court in Tarasoff II recognized the difficulty that a psychotherapist has in trying to forecast whether a patient presents a serious danger to an intended victim. ${ }^{178}$ The court does not expect the therapist to "render a perfect performance [but] the therapist need only exercise 'that reasonable degree of skill, knowledge, and care ordinarily possessed and exercise by members of [that professional specialty] under similar circumstances." 179 There has never been a similar circumstance in Dr. Goldstein's situation. The California Court of Appeals has gone beyond the California Supreme Court's decision in Tarasoff II when it decided that Dr. Goldstein's recommendation of hospitalization was inadequate and that he should have also warned Keith Ewing or law enforcement officials about Geno's threat. The Tarasoff II court also stated that a "therapist is free to exercise his or her own best judgment without liability; proof, aided by hindsight, that he or she judged wrongly is insufficient to establish negligence." ${ }^{180}$ Dr. Goldstein did exercise his best judgment in this case. He had a conversation with Geno's father and advised him to take Geno to the hospital. Again, Dr. Goldstein never examined or talked to Geno. His best judgment was to advise hospitalization and that should be all that is required of him in this circumstance. The court has decided to take the "proof, aided by hindsight" approach to this situation. ${ }^{181}$ There is no way Dr. Goldstein could have truly known Geno's intent or seriousness of the threat without the threat being conveyed directly to Dr. Goldstein.

The Pennsylvania Supreme Court in Emerich, relying on Tarasoff, stated that there must be a special relationship between the defendant and "the person whose conduct needs to be controlled ...."182 Both the Tarasoff courts and the Emerich court analyzed the issue of whether a patient and a

178. Tarasoff v. Regents of Univ. of Cal., 551 P.2d 334, 345 (Cal. 1976).

179. Id.

180. Id.

181. Id.

182. Emerich v. Philadelphia Ctr. For Human Dev., Inc., 720 A.2d 1032, 1036 (Pa. 1998). 
psychotherapist fall under the definition of special relationship. ${ }^{183}$ In the Ewing cases, the relationship between Dr. Goldstein and Geno Colello fell under the definition of special relationship as described by the Tarasoff and Emerich courts, but there was no special relationship between Victor Colello and Dr. Goldstein. ${ }^{184}$ The Tarasoff and Emerich courts point out that the relationship between physicians and patients is one of the main reasons to justify imposing the duty-to-warn. The Tarasoff II court stated that because the therapist "becomes sufficiently involved" in the patient's life, the therapist assumes "some responsibility" for the safety of the intended third-party victim. ${ }^{185}$ The emphasis is always on whether a special relationship exists. The special relationship allows the psychotherapist to delve into the patient's personal life and understand private intricacies like tone of voice and whether similar threats have been made in past. There was no way for Dr. Goldstein to know exactly Geno's condition. He never saw or spoke to Geno prior to or during Geno's hospitalization. All Dr. Goldstein had to rely on was a telephone call from Victor Colello. The California Court of Appeals felt that this one telephone call was enough to impose a duty upon Dr. Goldstein.

The Northridge court stated, so long as the therapist believes in the validity of the family member's statements, it is immaterial that the statements themselves do not come from the patient him/herself. The court specifically said, "it does not matter" that the communication came from someone other than the patient. ${ }^{186}$ However, it has to matter, especially given that neither Ewing court definitively determined who is considered a family member. The Goldstein court refused to define exactly what an immediate family member was and also refused to further consider what would happen if the communication came from someone other than a non-defined family member.

183. See Tarasoff II, 551 P.2d at 343-44; Tarasoff I, 529 P.2d at 557-59; Emerich, 720 A.2d at 1036-37. (All three courts refer to the Second Restatement Second of Torts in supporting the view that a duty arises only in the existence of a special relationship. The Restatement reads as follows:

There is no duty so to control the conduct of a third person as to prevent him from causing physical harm to another unless (a) a special relation exists between the actor and the third person which imposes a duty upon the actor to control the third person's conduct, or (b) a special relation exists between the actor and the other which gives to the other a right to protection.

RESTATEMENT(SECOND) OF TORTS § 315 (2004). RESTATEMENT(SECOND)OF TORTS: DUTY TO CONTROL CONDUCT OF THIRD PERSONS $§ 315$ (1965)).

184. Ewing v. Goldstein, 15 Cal. Rptr. 3d 865 (Cal. Ct. App. 2004). It may be that a special relationship as described in the cases and the Restatement did not exist between Art Capilla, an employee of the hospital, and Geno Colello. It is not probable from one brief meeting with Geno prior to his admittance into the hospital and one conversation with Victor Colello that the special relationship as described in the Restatement existed between Art and Geno. However, this article will not address or analyze whether a duty-to-warn should have ever existed between the hospital and the Ewings in light of the fact that a special relationship may or may not have existed between the social worker, hospital and Geno Colello.

185. Tarasoff II, 551 P.2d at 344.

186. Ewing v. Northridge Hosp. Med. Ctr., 16 Cal. Rptr. 3d 591, 596 (Cal. Ct. App. 2004). 
In America today, there are many different definitions of family. Many people live in households with what most would consider an "immediate family member." According to the 2000 census, there were 12,900,103 females that headed households with no husband present ${ }^{187}$ and 5,771,671 grandparents were the caregivers of one or more grandchildren under eighteen. ${ }^{188}$ There are at least 250,000 children in the United States being raised in same-sex households with one-fifth of the gay male couples and onethird of the lesbian couples identified in the 2000 census living in households with children. ${ }^{189}$ The 2000 census reported 658,711 same sex couples were living in the United States in the same house. ${ }^{190}$ These numbers are staggering. Is a same-sex partner a family member? Is a woman raising her best friend's child a family member? Is a grandparent an immediate family member? The Goldstein court left a gaping hole in California law when it decided not to address or define "immediate family member," but still held a psychotherapist to an affirmative duty based on information obtained from a non-defined "immediate family member." A case involving the communication to a psychotherapist by someone other than the patient has not been an issue in any other jurisdiction in the United States. However, other states have similar statutes and psychotherapist-patient privilege exceptions.

A Louisiana statute states that a psychotherapist will be not liable for breaking the confidentiality of their patient "[w]hen [the] patient has communicated a threat of physical violence ... against a clearly identified victim or victims, coupled with the apparent intent and ability to carry out that threat." ${ }^{.191}$ Similarly, an Indiana statute states that a mental health provider is not subject to civil liability if they fail to "(1) predict; or (2) warn or take precautions to protect from: a patient's violent behavior unless the patient has communicated to the provider of mental health services an actual threat of physical violence or other means of harm against a reasonably identifiable victim or victims ...."

187. U.S. Census Bureau, U.S. Dep't of Commerce, Households and Families: 2000, available at http://factfinder.census.gov/servlet/QTTable?_bm=y\&-geo_id=01000US\&-

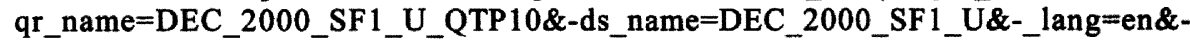
redoLog=false\&-_sse=on (last visited Mar. 9, 2005).

188. U.S. Census Bureau, Marital Status by Sex, Unmarried-Partner Households, and Grandparents as Caregivers: 2000, available at $\mathrm{http}: / /$ factfinder.census.gov/servlet/QTTable? $\mathrm{bm}=\mathrm{y} \&-\mathrm{geo}$ id $=01000 \mathrm{US} \&-\mathrm{qr}$ _name$=\mathrm{DEC}$ 2000_SF3_U_QTP18\&-ds_name $=$ DEC_ 2000_SF3_U\&-_lang=en\&-redoLog=false\&-_sse=on (last visited on Mar. 9, 2005).

189. Ğreg Barrett, In Gay Households, Familiar Endearments Acquire New Meaning, GANNETT NEwS SERV., Apr. 11, 2004, http://www.azcentral.com/families/articles/ 041 lgayparent1 1-CR.html (last visited Mar. 9, 2005).

190. U.S. Census Bureau, Marital Status by Sex, Unmarried-Partner Households, and Grandparents as Caregivers: 2000, available at $\mathrm{http}: / /$ factfinder.census.gov/servlet/QTTable? bm $=$ y\&-geo_id $=01000 U S \&-q r$ name $=$ DEC_2000_SF3_U_QTP18\&-ds_name $=$ DEC_2000_SF3_U\&-_lang=en\&-redoLog=false\&-_sse $=$ on (last visited on Mar. 9, 2005).

191. LA. REV. STAT. ANN. § 9:2800.2(A) (2004) (emphasis added).

192. IND. CODE § 34-30-16-1 (West 2005) (emphasis added). 
Furthermore, a Colorado statute states that no mental health professional or mental health hospital is civilly liable for failing to "warn or protect any person against a mental health patient's violent behavior ... except where the patient has communicated to the mental health care provider a serious threat of imminent physical violence against a specific person or persons." ${ }^{193}$ In Pennsylvania, a psychotherapist has a duty-to-warn "or an obligation to use reasonable care to protect the intended victim against such danger. The psychotherapist does not violate the psychotherapist-patient privilege when disclosing such patient communications." 194 In these instances, the communication that is protected and that triggers the dangerous person exception is when the information is communicated by the patient and not by the patient's agent or anyone else, including the patient's family member.

Additionally, the Supreme Court of Pennsylvania found, when it first recognized the mental health professional's duty-to-warn, "that the circumstances in which a duty to warn a third party arises are extremely limited."195 The court proposed a two prong test to determine when a limited duty-to-warn requirement should be imposed. First, whether there was a specific and immediate threat and, second, whether the victim was readily identifiable. ${ }^{196}$ The court recognized that a psychotherapist's treatment of a patient can produce "vague and imprecise threats . . . made by an agitated patient as a routine part of the relationship." 197 Dr. Goldstein did not have the opportunity to determine whether Geno's threat was vague and imprecise or to observe Geno's level of agitation when he made the threat because Geno never communicated the threat to Dr. Goldstein.

The Emerich court also stated "[s]trong reasons support the determination that the duty to warn must have some limits. "198 Dr. Goldstein used his common sense when he told Victor to take Geno to the hospital. The California court should have followed the same reasoning as the Emerich court by taking notice that Dr. Goldstein did use his prior analysis of Geno and common sense and that only in the instance had the threat come directly from Geno did Dr. Goldstein have a duty-to-warn Keith Ewing. Even the California statute explicitly says "patient" communication. ${ }^{199}$ A psychotherapist may, in some instances, need to rely on information received from a patient's family member to facilitate a patient's care, but to impose a duty

193. CoLo. REV. STAT. ANN. § 13-21-117 (West 2005) (emphasis added).

194. University of Pennsylvania Health System, $A$ Guide to Legal Issues in Health Care: Confidentiality, available at $\mathrm{http}: / / \mathrm{www} . u p h s . u p e n n . e d u / l e g a l / c o n f i d . h t m l$ (last visited Aug. 7, 2005) (emphasis added).

195. Emerich v. Philadelphia Ctr. For Human Dev., Inc., 720 A.2d 1032, 1040 (Pa. 1998) (emphasis added).

196. Id. (emphasis added).

197. Id.

198. Id. (emphasis added).

199. CAL. CIv. CODE $\S 43.92$ (a) (West 2005). 
upon the psychotherapist to warn an intended victim based on information received from family members goes beyond the limits of care.

On the other hand, the Ewing court put no limits on the duty of a psychotherapist to warn an intended victim of harm. The court could have followed the reasoning in preserving the psychotherapist-patient privilege similar to the Pennsylvania court. The Emerich court used the words "extremely limited" when discussing whether or not to allow an exception to this well protected privilege. ${ }^{200}$

Instead, the Ewing court indicated that it "does not matter" that the psychotherapist's belief or prediction of harm was premised on information from a member of the patient's family. ${ }^{201}$ However, the court noted it does matter if the belief was premised on information from someone other than a family member. Apparently, the distinction is significant. By saying, in a footnote, that this case applies only to family members opens the door to other causes of action based on information from a person who may not fit the legal definition of "family member." Thus, each case would be limited to an analysis of the status of the individual as a family member.

The slippery slope is going to start with the next victim and wrongful death suit; when the next victim dies because they were not warned by a psychotherapist from information provided by someone other than the patient; or when the next case is brought before the California courts claiming that someone's aunt, distant relative or friend should be considered an immediate family member and a doctor or hospital is liable for the death. Both Tarasoff decisions have had significant impact on most states and federal courts, especially in California. ${ }^{202}$ The $E$ wing cases will likely have a similar impact. To date, fifty-one cases have followed Tarasoff II and an additional twentyfive cases have had concurring opinions using Tarasoff $I I$ to recognize the duty-to-warn requirement. The California Court of Appeals would probably not agree that it has broadened the statute or may have created a slippery slope, but look at the impact that just the Tarasoff cases have had on the American court system as well as the impact from broadening a well regarded and protected psychotherapist-patient privilege. The effect and fallout can be astronomical.

\section{CONCLUSION}

Privileges are not taken lightly in the courts. The United States Supreme Court has stated that "[e]videntiary privileges in litigation are not favored,"203

200. Emerich, 720 A.2d at 1040.

201. Northridge Hosp., 16 Cal. Rptr. 3d at 596 (Cal. Ct. App. 2004).

202. Tarasoff $I$ has been cited in fifty-nine law review articles, one statute and twelve treatises while the Tarasoff II decision has been cited in 762 law review articles, two restatements, five statutes, 128 treatises and eleven American Law Reports.

203. Herbert v. Lando, 441 U.S. 153, 175 (1979). 
and " $[w]$ hatever their origins, these exceptions to the demand for every man's evidence are not lightly created nor expansively construed for they are in derogation of the search for truth." 204 The Goldstein court has expansively construed, and has lightly created the psychotherapist-patient privilege when it found that the family member's communication with the therapist must be protected. By protecting the non-patient communication, the Ewing courts, in turn, have provided a level of confidentiality to the family member. There must be a privilege before one can invoke the dangerous person exception, and the Goldstein court extended this protection when it expanded the psychotherapist-patient privilege by protecting non-patient communications and imposing the duty-to-warn on the psychotherapist.

A patient's privileged relationship with a physician or psychotherapist are to be highly regarded. Patients need to be protected, and any and all exceptions should be very limited. The Sixth Circuit Court of Appeals stated that the psychiatric patient "exposes ... not only what his words directly express; he lays bare his entire self, his dreams, his fantasies, his sins, and his shame." 205 The court furthered that "[i]t would be too much to expect them to do so if they knew that all they say-and all that the psychiatrist learns from what they say-may be revealed to the whole world from a witness stand."206

Psychotherapists should be encouraged to use their professional judgment in determining whether information about the threat a patient poses is information that would require breaking the highly regarded confidence and privilege that courts have been very careful to create. However, allowing the use of information obtained from someone that is not privy to that confidence and privilege is wrong. Nonetheless, there are greater consequences when a court imposes a duty-to-warn on a psychotherapist and any hospital staff when threatening information has been obtained from a non-patient, non-privilege protected "immediate family member."

204. United States v. Nixon, 418 U.S. 683, 710 (1974) (emphasis added).

205. Zuniga, 714 F.2d at 638. (quoting Taylor v. United States, 222 F.2d 398, 401 (D.C. Cir. 1955)). 